\title{
当院におけるリスフラン関節脱臼骨折の治療成績
}

\author{
金 澤 和 貴*, 吉 村 一 朗*, 井 田 敬 大*, \\ 竹 山 昭 徳*, 内藤 正 俊*, 井上敏 生**
}

\section{Clinical Results of Lisfranc Joint Fracture-Dislocation}

Kazuki Kanazawa*, Ichiro Yoshimura*, Takahiro Ida*, Akinori Takeyama*, Masatoshi Naito*, and Toshio Inoue ${ }^{* *}$

1996 2004 年の間に治療を行ったリスフラン関節脱臼骨折は 7 例 7 足（全例男性）で，このうち陳旧 例 1 例を除く 6 例 6 足に対し後ろ向き調査を施行した。年齢は 21 58 歳（平均 34.7 歳）で，経過観察期 間は 4 30 ヶ月（平均 15.3 ヶ）であった。骨折型は Hardcastle 分類で type A は 3 足， type B は 2 足, type C は 1 足で受傷原因は交通事故 3 足, 労働災害 3 足であった.リスフラン関節脱臼骨折は見逃 され陳旧化した場合やリスフラン関節の正確な整復を㤐ると疼痛の原因になるため注意が必要である.

We performed a retrospective study of patients (six adult men) who underwent open reduction and screw/K-wire/plate fixation for Lisfranc joint injuries during a nine-year period. According to Hardcastle's classification, three cases were type A, two cases were type B, and one case was type C. The average JSSF midfoot scale was 77 points. Open reduction and internal fixation can be a good choice for the treatment of Lisfranc joint fracture-dislocations. Incongruity of Lisfranc joint was due to persistent ache.

Key words : Lisfranc joint fracture-dislocation (リスフラン関節脱臼), Hardcastle's classification (ハードキャッスル分類), surgical treatment (手術療法)

\section{は じめ に}

リスフラン関節脱臼骨折は様々な愁訴が残存しやす い骨折である.今回当院で加療を行った症例の治療成 績および成績不良因子について検討を行ったので報告 する.

\section{対象および方法}

1996〜2004 年の間に治療を行った症例は 7 例（全 例男性）で, このうち陳旧例 1 例を除く 6 例を対象之 した. 年齢は $21 \sim 58$ 歳（平均 34.7 歳）で，経過観察 期間は 4〜30 ヶ月（平均 15.3 ヶ月）であった。これ らの症例の骨折型, 受傷原因, 内固定法, 手術時期, JSSF midfoot scale（2006 年 3 月における電話での 聞き取り調査）について検討を行った。
結

果
骨折型は Hardcastle 分類で type A は3 足, type B は 2 足, type $\mathrm{C}$ は 1 足で受傷原因は交通事故 3 足, 労災 3 足であった。内固定は全例観血的に手術を行い K-wire のみによる固定が 2 足，K-wire と screwに よる固定が 2 足, K-wire と plate による固定が 1 足, screw による固定が 1 足であった. JSSF midfoot scale は 24〜100 点で平均 77 点であった．愁訴は最終 調査時のレントゲンで骨萎縮の強い例・開放骨折・足 根骨に多くの骨折を伴う例・リスフラン関節の整復が 不良な例・リスフラン関節やその隣接関節の関節症性 变化の程度が強い程疼痛が残存しやすい傾向を認めた （表 1).

\footnotetext{
* 福岡大学整形外科 Department of Orthopedic Surgery, Fukuoka University School of Medicine, Fukuoka, Japan

** 白十字病院整形外科 Department of Orthopedic Surgery, Hakujyuji Hospital, Fukuoka, Japan
} 
表 1

\begin{tabular}{c|l|c|c|c|c}
\hline \hline 症例 & \multicolumn{1}{|c|}{ 受傷原因 } & 手術時期 & Hardcastle 分類 & 内固定法 & JSSF \\
\hline $1(56 \mathrm{y})$ & 鉄板にはさまれる & 7 & $\mathrm{~A}$ & $\begin{array}{c}\text { K-wire } \\
\text { screw }\end{array}$ & 85 \\
\hline $2(58 \mathrm{y})$ & 重機にはさまれる & 当日 & $\mathrm{A}$ & K-wire & 24 \\
\hline $3(19 \mathrm{y})$ & バイク事故 & 2 & $\mathrm{C}$ & $\begin{array}{l}\text { K-wire } \\
\text { plate }\end{array}$ & 100 \\
\hline $4(19 \mathrm{y})$ & バイク事故 & 11 & B & $\begin{array}{l}\text { K-wire } \\
\text { screw }\end{array}$ & 75 \\
\hline $5(21 \mathrm{y})$ & 車走行中衝突 & 13 & B & screw & 87 \\
\hline $6(33 \mathrm{y})$ & 重機にはさまれる & 9 & A & K-wire & 90 \\
\hline
\end{tabular}

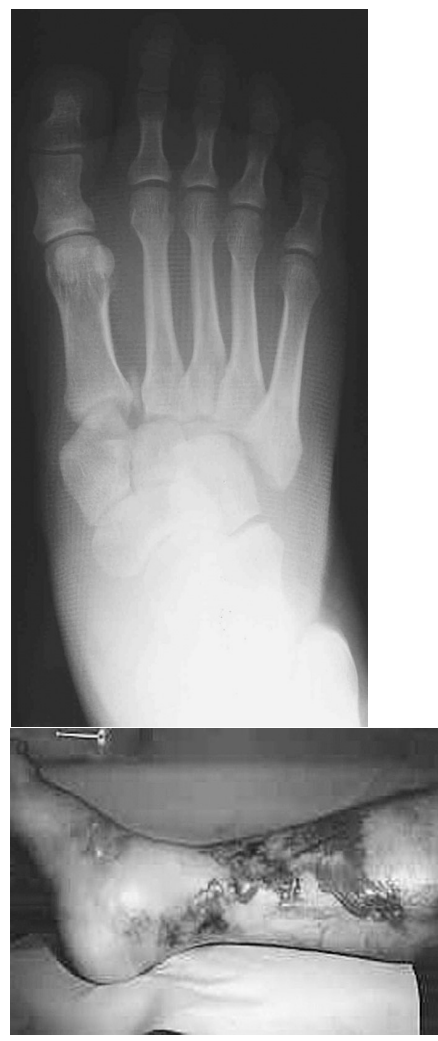

(a)
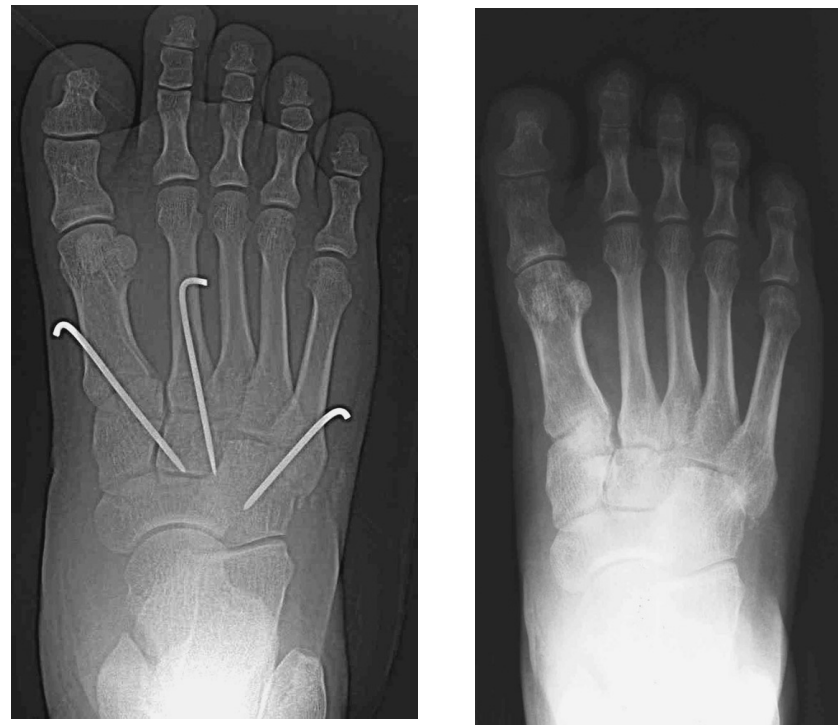

(b)

図 1 a ）: 受傷当日の X-p.

Hardcastle 分類 Type A の Lisfranc 関節脱臼骨折を認める.

足部から下腿にかけて腫脹と皮膚に水疱の形成を認める.

b ) : 術直後の X-p.

観血的に整復し K-wire で固定.

c ）: 術後 14 ヶ月の X-p.

軽度の関節症变化を認める. 


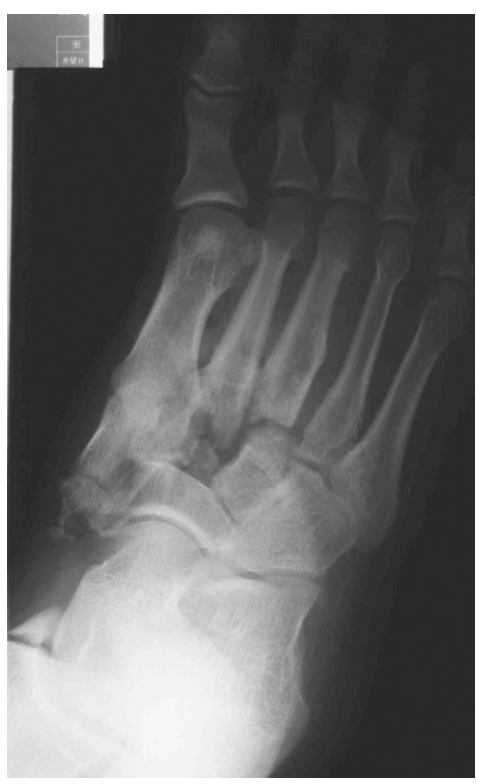

(a)

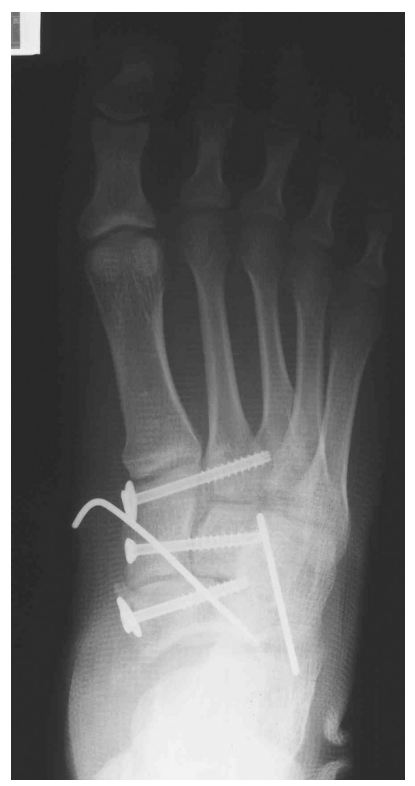

(b)

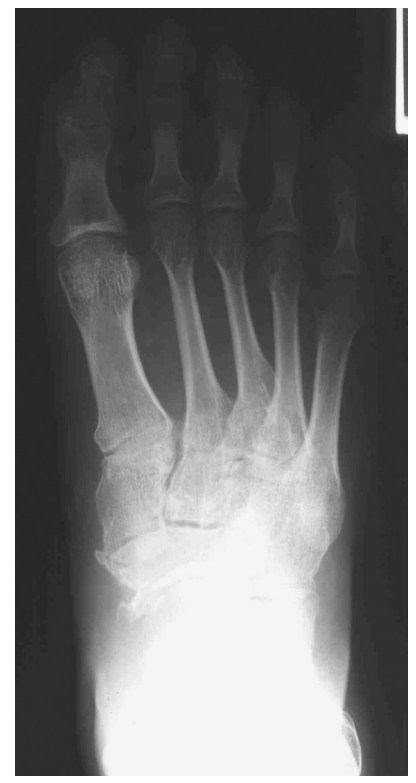

(c)

図 2 a ）: 受傷当日の X-p.

舟状骨骨折を伴う Hardcastle 分類 Type B の Lisfranc 関節 脱臼骨折を認める.

b ) : 術直後の X-p.

観血的に整復し K-wire と C.C.S で固定.

c ) : 術後 30 ヶ月の X-p.

中等度の関節症变化を認める.

症

例

33 歳男性.

作業中，重機に右足をはさまれ受傷．足部から下腿に かけて腫脹強いため受傷後 9 日目に観血的手術を施行. 術後 6 週で抜釘し足底装具装着にて歩行開始した。術 後 14 ヶ月の最終調査時のレントゲンでは軽度の関節 症変化を認め, 術後 2 年の調査時には長時間歩行後の 疼痛を認め JSSF midfoot scaleは 90 点であった (図 $1: a \sim c$ ).

\section{9 歳男性.}

バイク走行中トラックと衝突し転倒受傷. 受傷後 11 日目に観血的手術を施行。術後 7 週で舟状骨以外の K-wire，screw を抜釘し足底装具装着にて歩行開始 した。術後 2 年に舟状骨部の screw を抜去し，術後 2.5 年の最終調查時のレントゲンでは中等度の関節症
变化を認め, 術後 8 年の調查時には歩行時疼痛のため 常に足底装具を必要とし JSSF midfoot scale は 75 点であった（図 $2: a 〜 c)$.

考察

リスフラン関節脱臼骨折は全骨折の $0.2 \%$ 程度の比 較的稀な骨折で多発外傷に伴うことが多い骨折である. 以前 Aitkin ら ${ }^{1)}$ は解剖学的整復の重要性を訴えてい なかったが最近の報告は脱臼骨折の正確な解剖学的整 復の必要性を述べている報告が多く一般的である。 Myerson ら ${ }^{6)}$ は多発外傷例において約 20\%に初診時 に見逃しがあると報告しており注意を要す。三箇島 $ら^{4)}$ ，星野 ${ }^{2)}$ ，仁木 ${ }^{7)}$ はリスフラン関節脱臼骨折の成 績不良因子として 1 ) 第 1 ， 2 中足骨基部間の整復不 良 2 ) 第 2 5 中足・足根関節の整復不良 3 ）中足骨 頝部骨折の整復不良 4) コンパートメント症候群 5) 感染 6) 外傷性変形性関節症 7) 創傷治癒遅延 8) 
陳旧例を挙げている，治療成績を向上するためには非 観血的に脱臼・骨折が整復できなければ躊躇なく観血 的に解剖学的整復を確実に行うことが鉄則である。固 定方法としてKuo ら ${ }^{3)}$ は第 $1 \sim 3$ 中足・足根関節は螺 子による固定，第 4 5 中足・足根関節は K-wire に よる固定をすすめている。また骨以外の組織に対して は軟部組織の腫脹を最小限にとどめることが最重要で, 手術時期として受傷当日が最も良いが，不可能な場合 十分に腫脹がおさまるまで待機して手術を行うべきだ と思われる. 本症例では受傷後より平均 7 日後に全例 観血的に手術を行い開放骨折の 1 例を除きJSSF midfoot scale が 75 点以上とある程度良好な成績を得 られていた。足部の腫脹が強くコンパートメント症候 群を疑った場合, 足底筋の麻痺や鉤爪趾变形を起こし それにより成績不良の原因になるため Myerson ら ${ }^{5)}$ の方法に従い足趾の他動的ストレッチによる疼痛増悪 の有無, 足部区画内圧を測定し $30 \mathrm{mmHg}$ を超える症 例は足部背側進入もしくは内側進入による筋膜切開の 必要性がある。本症例の荷重時期は平均 7 週で Lisfranc 関節に K-wire が抻入固定されている場合抜 釬後足底挿板装着し荷重を開始した。しかし最終調査 時のレントゲンで全例骨萎縮を認め, 疼痛の原因の一 つになっていると思われた。一般的に荷重時期は 4〜8 週と様々であるが，骨萎縮による疼痛や関節軟 骨の变性を防ぐためにも骨折の程度にもよるが 4 週前 後の早期荷重を行うことが望ましいと思われる。その ためには可能な限り螺子による強固な固定を行うこと
が成績向上の重要な因子になると思われた。

ま と め

1）過去 9 年間に加療し, 経過観察可能であったリス フラン関節脱臼骨折 6 例 6 足に対し治療成績を検 討した。

2 ）全症例の JSSF midfoot scale は開放骨折の 1 例 は 24 と著しく点数が低かったが平均 77 点と大部 分で良好であった。

\section{参 考 文 献}

1) Aitken, A. P., Paulson, D. : Dislocations of the tarsometatarsal joint. J. Bone Joint Surg., 45A : 246-260, 1963.

2）星野雄志ほか：リスフラン関節脱臼骨折の治療経験. 骨折, 25(2) : 543-546, 2003.

3) Kuo, R. S., et al. : Outcome after open reduction and internal fixation of Lisfranc joint injuries. J. Bone Joint Surg., 82A : 1609-1618, 2000.

4）三箇島吉統ほか：Lisfranc 関節脱臼骨折の成績不良因 子に対する検討。整形外科, 56(11)：1425-1429， 2005.

5) Myerson, M. S. : Management of compartment syndromes of the foot. Clin. Orthop., 271 : 239-248, 1991.

6) Myerson, M. S., et al. : Fracture dislocations of the tarsometatarsal joints; end results correlated with pathology and treatment. Foot Ankle Int., 6 : 225-242, 1986.

7）仁木久照：前足部の関節内骨折. 新 OS NOW 関節内 骨折の手技一その最新手技，18：198-209，2003. 